\title{
Complicated Gitelman syndrome and autoimmune thyroid disease: a case report with a new homozygous mutation in the SLC12A3 gene and literature review
}

Haiyang Zhou', Xinhuan Liang ${ }^{\dagger}$, Yingfen Qing, Bihui Meng, Jia Zhou, Song Huang, Shurong Lu, Zhenxing Huang, Haiyan Yang, Yan Ma and Zuojie Luo

\begin{abstract}
Background: Gitelman syndrome (GS) is an inherited autosomal recessive renal tubular disorder characterized by low levels of potassium and magnesium in the blood, decreased excretion of calcium in the urine, and elevated blood pH. GS is caused by an inactivating mutation in the SLC12A3 gene, which is located on the long arm of chromosome 16 (16q13) and encodes a thiazide-sensitive sodium chloride cotransporter (NCCT).

Case presentation: A 45-year-old man with Graves' disease complicated by paroxysmal limb paralysis had a diagnosis of thyrotoxic periodic paralysis for 12 years. However, his serum potassium level remained low despite sufficiently large doses of potassium supplementation. Finally, gene analysis revealed a homozygous mutation in the SLC12A3 gene. After his thyroid function gradually returned to normal, his serum potassium level remained low, but his paroxysmal limb paralysis resolved.

Conclusions: GS combined with hyperthyroidism can manifest as frequent episodes of periodic paralysis; to date, this comorbidity has been reported only in eastern Asian populations. This case prompted us to more seriously consider the possibility of GS associated with thyroid dysfunction.
\end{abstract}

Keywords: Gitelman syndrome, Graves' disease, Hypokalemia

\section{Background}

Gitelman syndrome (GS) is an inherited autosomal recessive renal tubular disorder characterized by low levels of potassium and magnesium in the blood, decreased excretion of calcium in the urine, and elevated blood $\mathrm{pH}$. GS is caused by an inactivating mutation in the SLC12A3 gene, which is located on the long arm of chromosome 16 (16q13) and encodes a thiazide-sensitive sodium chloride cotransporter (NCCT). Graves' disease (GD) is a common cause of hyperthyroidism. In our department, we diagnosed a patient with GD and GS.

\footnotetext{
*Correspondence: luoma628@163.com; zhouhaiyang4000@163.com ${ }^{\dagger}$ Haiyang Zhou and Xinhuan Liang contributed equally to this work. The Department of Endocrinology, The First Affiliated Hospital of Guangxi Medical University, Nanning 530021, China
}

\section{Case presentation}

The patient was a 45 -year-old male with a 12-year history of paroxysmal weakness of the limbs. He was diagnosed with hypokalemic periodic paralysis in 2005 and hyperthyroidism in 2008. He had taken antithyroid drugs on an irregular basis since 2008 but had not undergone proper biochemical examination. Whenever he felt that his weakness was becoming severe, he would self-prescribe potassium chloride. In June 2017, the extent of his lower limb weakness increased such that he could no longer walk. He took potassium chloride without improvement. Subsequently, he was admitted to another hospital. His temperature was $36.7^{\circ} \mathrm{C}$, and his pulse was 96 beats/min. The muscle strength in his lower limbs was grade II [1], and that in his upper limbs was grade III. His limb muscle tone was normal. His electrolyte and blood marker levels were as follows: $\mathrm{K}^{+}, 1.4 \mathrm{mmol} /$ l; $\mathrm{Na}^{+}, 138 \mathrm{mmol} / \mathrm{l}, \mathrm{Cl}^{-}, 97 \mathrm{mmol} / \mathrm{l} \mathrm{Ca}^{2+}, 2.61 \mathrm{mmol} / \mathrm{l}$; free

(c) The Author(s). 2018 Open Access This article is distributed under the terms of the Creative Commons Attribution 4.0 International License (http://creativecommons.org/licenses/by/4.0/), which permits unrestricted use, distribution, and reproduction in any medium, provided you give appropriate credit to the original author(s) and the source, provide a link to the Creative Commons license, and indicate if changes were made. The Creative Commons Public Domain Dedication waiver (http://creativecommons.org/publicdomain/zero/1.0/) applies to the data made available in this article, unless otherwise stated. 
triiodothyronine (FT3) $6.96 \mathrm{pmol} / \mathrm{l}(1.86-6.44)$; free thyroxine (FT4) $38.96 \mathrm{mIU} / \mathrm{l}$ (11.45-22.14); thyroid-stimulating hormone $(\mathrm{TSH})<0.01 \mathrm{mIU} / 1(0.4-4.5)$; thyroglobulin antibody (TgAb) $16.61 \mathrm{IU} / \mathrm{ml}(0-150)$; and thyrotropin receptor antibody (TRAb) $22.36 \mathrm{mIU} / \mathrm{l}$ (0-5). Thyroid ultrasound demonstrated diffuse thyromegaly with a rich blood supply. The patient was diagnosed with GD and hypokalemic periodic paralysis and was treated with propylthiouracil (PTU) and potassium chloride. However, 2 days later, despite improvement of his weakness, his temperature increased to $41{ }^{\circ} \mathrm{C}$, and he experienced cough and expectoration. Computed tomography $(\mathrm{CT})$ imaging of his lungs revealed pneumonia. He was subsequently treated with cefazolin and transferred to our hospital 2 days later.

When the patient was admitted to our department, his limb weakness had significantly improved. He had a temperature of $38.8^{\circ} \mathrm{C}$, a pulse of 96 beats/min, a breathing rate of 20 respirations/min, a blood pressure of 106/ $68 \mathrm{mmHg}$, and grade II thyroid enlargement. Vascular murmur was audible in the thyroid. The muscle strength in his limbs was grade $\mathrm{V}$, and his limb muscle tone was normal. The patient's biochemical parameters were as follows (the reference values are different from those used in the previous department): [blood count] leukocytes $13.10 \times 10^{9} /$, neutrophils $11.99 \times 10^{9} / \mathrm{l}$ and hemoglobin $13.3 \mathrm{~g} / \mathrm{dl}$; [serum electrolytes] $\mathrm{K}^{+} 2.110 \mathrm{mmol} / \mathrm{l}, \mathrm{Na}^{+} 131.6 \mathrm{mmol} / \mathrm{l}, \mathrm{Cl}^{-}$ $91.1 \mathrm{mmol} / \mathrm{l}, \mathrm{Ca}^{2+} 1.850 \mathrm{mmol} / \mathrm{l}$, and $\mathrm{Mg}^{2+} 0.540 \mathrm{mmol} / \mathrm{l}$; [thyroid function and thyroid antibodies] triiodothyronine (T3) $1.40 \mathrm{mmol} / \mathrm{l}(1.34-2.75)$, thyroxine (T4) > $300 \mathrm{nmol} / \mathrm{l}$ (78.38-157.40), FT3 $5.32 \mathrm{pmol} / \mathrm{l} \quad(3.60-6.00), \quad$ FT4 $51.23 \mathrm{pmol} / \mathrm{l}$ (7.86-14.41), TSH $0.01 \mathrm{mIU} / \mathrm{l}(0.34-5.65)$, thyroid peroxidase antibody (TPOAb) $36.33 \mathrm{IU} / \mathrm{ml}(0-30)$, TRAb $9.011 \mathrm{IU} / \mathrm{ml}(0-30), \operatorname{TgAb} 6.04 \%(<30 \%)$, and thyroid microsomal antibody (TMAB) $6.48 \%(<20 \%)$; and creatine kinase (CK) $1398 \mathrm{U} / 1$ (38-174) and CK-MB 29 U/l (0.025.0). The patient's liver and kidney functions were normal. We treated him with cefazolin, propranolol, PTU and potassium chloride. The patient's vital signs and strength normalized after 3 days, and his leukocyte count had decreased to $5.97 \times 10^{9} /$ l, his neutrophils had decreased to $3.59 \times 10^{9} /$ l, and his CK had decreased to $40 \mathrm{U} / \mathrm{l}$. However, his serum potassium level remained low despite $24 \mathrm{~g} / \mathrm{d}$ of potassium supplementation. Additionally, the patient had hypomagnesemia and metabolic alkalosis (the results are shown in Tables 1 and 2). Further testing showed that his renin activity (supine) was $5.17 \mathrm{ng} / \mathrm{ml} / \mathrm{h}$ (reference value 0.15 2.33), his aldosterone level was $436.10 \mathrm{pg} / \mathrm{ml}(10-160)$, his random urinary calcium/creatinine ratio was 0.23 , his osteocalcin level was $1.06 \mathrm{ng} / \mathrm{ml}(6.00-48.00)$, his parathyroid hormone level was $11.22 \mathrm{pg} / \mathrm{ml}(6.0-80.0)$ and his calcitonin level was $4.87 \mathrm{pg} / \mathrm{ml}(0.00-18.00)$.

Based on these results, we suspected that the patient did not have thyrotoxic periodic paralysis (TPP) but rather GS. Therefore, we sent a blood sample to Beijing Huada Company for sequencing. The Next Generation Sequencing (NGS) was used. The sequencing protocol was based on the Roche Nimblegen SeqCap EZ Choice XL Library for exon trapping. A total of 25 genes (Table 3) known to be associated with hypokalemia were targeted and the total size of target regions was $11.8 \mathrm{M}$. Libraries were prepared with the Kapa Hyper Prep kit and sequencing was carried out by Illumina NextSeq500 System. The sequencing data were compared to the human genome by BWA (0.7.12-r1039) software (http://bio-bwa.sourceforge.net/), and ANNOVAR (Date: 2015-06-17) was used to annotate the mutation sites based on dbSNP, Clinvar, ExAC, and 1000 genomes, among others. We found a homozygous mutation in the SLC12A3 gene (Exon12 1562-1564delTCA) with an amino acid change of 522dellle, which was first reported as a compound heterozygous mutation.by Vargas-Poussou [2]. The mutation was confirmed by sanger sequencing. No other phenotypes were found, including those for Bartter syndrome, hypokalemic periodic paralysis,Liddle syndrome, hyperaldosteronism, and apparent mineralocorticoid excess. The diagnosis was changed to GD with GS. Moreover, we obtained blood samples from the patient's mother and son (his father had passed away) who did not have hypokalemia and hyperthyroidism. Both of them were proved as heterozygous mutation carriers by sanger sequencing. The sequencing chromatograms are shown in Figs. 1 and 2. The patient had three brothers and one sister, but we were unable to obtain blood samples from them.

In addition to antithyroid drugs (methimazole $30 \mathrm{mg} / \mathrm{d}$ ), we gave the patient potassium chloride $(3 \mathrm{~g} / \mathrm{d})$, potassium citrate $(6 \mathrm{~g} / \mathrm{d})$, and magnesium potassium aspartate $(1.788 \mathrm{~g} / \mathrm{d})$. At the follow-up

Table 1 Serum and urine electrolyte levels on admission

\begin{tabular}{|c|c|c|c|c|}
\hline & \multicolumn{2}{|l|}{ 24th July } & \multicolumn{2}{|l|}{ 5th August } \\
\hline & Urine electrolytes & Serum electrolytes & Urine electrolytes & Serum electrolytes \\
\hline $\mathrm{K}(\mathrm{mmol} / \mathrm{l})$ & 214.05 & 2.850 & 245.71 & 3.550 \\
\hline $\mathrm{Ca}(\mathrm{mmol} / \mathrm{l})$ & 4.80 & 2.303 & 2.91 & 2.309 \\
\hline $\mathrm{Mg}(\mathrm{mmol} / \mathrm{l})$ & 6.40 & 0.720 & 3.35 & 0.54 \\
\hline Urine volume (ml) & 3200 & - & 3100 & - \\
\hline
\end{tabular}


Table 2 Blood gas analysis on admission

\begin{tabular}{llll}
\hline & 22nd Jul & 24th Jul & 4th Aug \\
\hline $\mathrm{pH}$ & 7.602 & 7.499 & 7.447 \\
$\mathrm{PCO}_{2}$ & 26.1 & 31.9 & 37.7 \\
$\mathrm{PO}_{2}$ & 78.3 & 91.3 & 93.0 \\
$\mathrm{HCO}_{3}{ }^{-}$ & 25.2 & 24.3 & 25.4 \\
$\mathrm{BE}$ & 5.0 & 1.8 & 1.6 \\
$\mathrm{~K}^{+}$ & 1.92 & 2.72 & 2.67 \\
$\mathrm{Ca}^{2+}$ & 1.03 & 0.97 & 1.03 \\
$\mathrm{Cl}^{-}$ & 93 & 102 & 100 \\
\hline
\end{tabular}

visit, we found that the patient often forgot to take his medicine. The results for thyroid function and electrolyte levels before and after treatment are listed in Table 4, which indicated that the patient's thyroid function had improved. Hypothyroidism occurred during the course of treatment, but the patient's thyroid function returned to normal after we reduced the dose of methimazole. The patient refused the recommendation to undergo $\mathrm{I}^{131}$ therapy. His serum potassium level remained low despite a sufficiently large daily dose of potassium, but no paroxysmal paralysis occurred after discharge.

\section{Discussion and conclusions}

More than 400 SLC12A3 variations have been identified to date. The prevalence of GS among Japanese populations is $10.3 / 10000[3,4]$. The incidence rates of GD and Hashimoto's thyroiditis (HT) among the Chinese population are 120/100000/year and 100/ 100000 /year, respectively [5]. The prevalence rates of both autoimmune thyroid disease (AITD) and GS among East Asian populations are higher than those among European populations [6]. Through a Chinese and English literature review, we identified 17 cases of AITD complicated with GS from nine papers (18 cases including ours) [7-17]. The cases included seven males (aged 20 45 years) and 11 females (aged 14 50 years). Among the patients, 13

Table $\mathbf{3}$ The list of genes in the panel

\begin{tabular}{lll}
\hline SLC12A3 & SCN4A & KCNJ2 \\
SLC12A1 & HSD11B2 & ATP6V0A4 \\
KCNJ1 & KCNJ5 & KCNJ10 \\
CLCNKB & SCCN1B-exon13 & SLC34A1 \\
BSND & SCCN1G-exon13 & EHHADH \\
CLCNKA & CYP11B1 & HNF4A \\
CASR & CTP17A1 & SLC4A1 \\
CACNA1S & NR3C1 & \\
KCNE3 & CACNA1D & \\
\hline
\end{tabular}

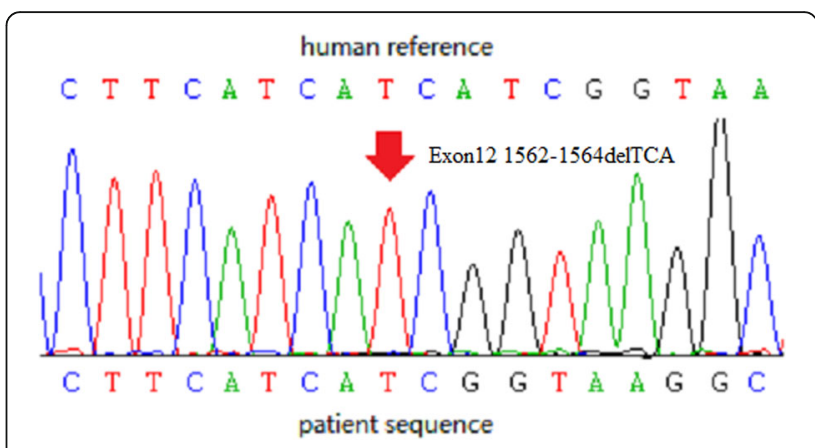

Fig. 1 NGS sequencing of the SLC12A3 gene fragment encompassing homozygous mutation c.1562_1564delTCA in patient

had GD, 3 had HT, and two had antibody-positive AITD. All patients with GD and HT developed hypokalemic periodic paralysis. Twelve patients underwent genetic analysis, and all mutations were located in the SLC12A3 gene; four patients were homozygotes, one was a heterozygote, and five were complex heterozygotes. One patient did not have any detectable mutation, and the mutation type for one patient was not mentioned. The details of these cases are listed in Tables 5 and 6. Except for our case, the mutations in all cases were single base substitutions; two of the mutations were T60 M [18], which is a common variation among Chinese individuals. Six patients underwent renal biopsy, and all of the patients had juxtaglomerular complex (JGC) hyperplasia. Patient 6 had clinical and pathological features of GS but a wild-type SLC12A3 gene; therefore, the patient may have had acquired GS caused by autoimmune disease [19, 20]. Interestingly, we noticed that all the reported cases were from eastern Asia, possibly because of the high prevalence of GS and AITD in East Asian populations.

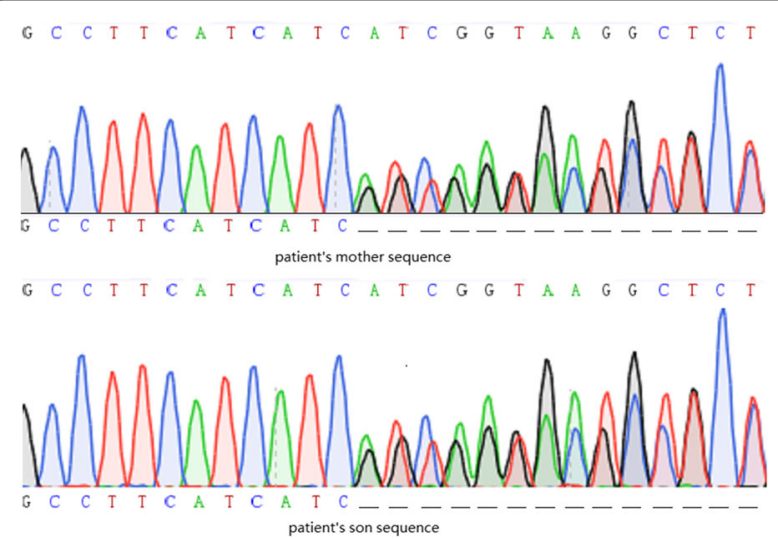

Fig. 2 Sanger sequencing of the SLC12A3 gene fragment encompassing heterozygous mutation c.1562_1564delTCA in patient mother(above) and 
Table 4 Most recent re-examination results

\begin{tabular}{|c|c|c|c|c|c|c|c|}
\hline & $\begin{array}{l}\text { SerumK }{ }^{+} \\
(\mathrm{mmol})\end{array}$ & $\begin{array}{l}\text { Serum } \mathrm{Mg}^{2+} \\
(\mathrm{mmol})\end{array}$ & $\begin{array}{l}\text { T3 } \\
(\mathrm{nmol} / \mathrm{l})\end{array}$ & $\begin{array}{l}\mathrm{T} 4 \\
(\mathrm{nmol} / \mathrm{l})\end{array}$ & $\begin{array}{l}\text { FT3 } \\
\text { (pmol/l) }\end{array}$ & $\begin{array}{l}\text { FT4 } \\
(\mathrm{pmol} / \mathrm{l})\end{array}$ & $\begin{array}{l}\text { TSH } \\
(\mathrm{mlU} / \mathrm{l})\end{array}$ \\
\hline 2017.22nd Jul (admission) & $2.110 \downarrow$ & $0.540 \downarrow$ & 1.40 & $>300 \uparrow$ & 5.32 & $51.23 \uparrow$ & $0.01 \downarrow$ \\
\hline 5th.Aug & 3.550 & $0.520 \downarrow$ & - & - & - & - & - \\
\hline 18th Aug (discharge) & $2.580 \downarrow$ & $0.540 \downarrow$ & $2.75 \uparrow$ & $189.53 \uparrow$ & $8.88 \uparrow$ & $20.77 \uparrow$ & $0.01 \downarrow$ \\
\hline 19th Sep & $2.810 \downarrow$ & $0.700 \downarrow$ & $2.63 \uparrow$ & $114.75 \uparrow$ & $6.69 \uparrow$ & $15.81 \uparrow$ & $0.01 \downarrow$ \\
\hline 27th Oct & $2.530 \downarrow$ & $0.700 \downarrow$ & - & - & 4.33 & 3.85 & $1.39 \downarrow$ \\
\hline 12th.Dec & $2.360 \downarrow$ & $0.700 \downarrow$ & - & - & $2.64 \downarrow$ & $1.87 \downarrow$ & $38.87 \uparrow$ \\
\hline 2018.8th.Feb & $2.440 \downarrow$ & $0.680 \downarrow$ & - & - & 4.00 & 8.46 & $5.23 \uparrow$ \\
\hline 28th.Mar & - & - & - & - & 4.45 & 9.59 & $5.43 \uparrow$ \\
\hline
\end{tabular}

Table 5 Pathology and gene information for the reported cases to date

\begin{tabular}{|c|c|c|c|c|c|c|c|c|c|}
\hline No & Sex & Age & $\begin{array}{l}\text { Thyroid } \\
\text { disease }\end{array}$ & $\begin{array}{l}\text { Diagnosis } \\
\text { method }\end{array}$ & Pathology & Mutation type & Variation site & $\begin{array}{l}\text { Change in } \\
\text { nucleotide } \\
\text { base }\end{array}$ & $\begin{array}{l}\text { Change in } \\
\text { amino acid }\end{array}$ \\
\hline 1 & Male & 45 & GD & $\begin{array}{l}\text { Gene } \\
\text { analysis }\end{array}$ & No mention & Homozygote & Exon 12 & $\begin{array}{l}\text { 1562- } \\
\text { 1564delTCA }\end{array}$ & 522dellle \\
\hline \multirow[t]{2}{*}{$2[7]$} & \multirow[t]{2}{*}{ Male } & \multirow[t]{2}{*}{39} & \multirow[t]{2}{*}{ GD } & \multirow{2}{*}{$\begin{array}{l}\text { Gene } \\
\text { analysis }\end{array}$} & \multirow[t]{2}{*}{ No mention } & \multirow{2}{*}{$\begin{array}{l}\text { Compound } \\
\text { heterozygote }\end{array}$} & Exon 15 & 1841C-T & Ser614Phe \\
\hline & & & & & & & Exon 26 & 2968G-A & Arg990Lys \\
\hline \multirow[t]{2}{*}{3 [7] } & \multirow[t]{2}{*}{ Female } & \multirow[t]{2}{*}{41} & \multirow{2}{*}{$\begin{array}{l}\text { Antibody- } \\
\text { positive }\end{array}$} & \multirow{2}{*}{$\begin{array}{l}\text { Gene } \\
\text { analysis }\end{array}$} & \multirow[t]{2}{*}{ No mention } & \multirow{2}{*}{$\begin{array}{l}\text { Compound } \\
\text { heterozygote }\end{array}$} & Intron 7 & $964+2 T-C$ & \\
\hline & & & & & & & Exon 1 & $179 C-T$ & Thr60Met \\
\hline \multirow[t]{2}{*}{$4[8]$} & \multirow[t]{2}{*}{ Female } & \multirow[t]{2}{*}{40} & \multirow{2}{*}{$\begin{array}{l}\text { Antibody- } \\
\text { positive }\end{array}$} & \multirow{2}{*}{$\begin{array}{l}\text { Gene } \\
\text { analysis }\end{array}$} & \multirow[t]{2}{*}{ No mention } & \multirow{2}{*}{$\begin{array}{l}\text { Compound } \\
\text { heterozygote }\end{array}$} & Exon 22 & $2552 \mathrm{~T}-\mathrm{A}$ & Leu849His \\
\hline & & & & & & & Exon 22 & 2561G-A & Arg $852 \mathrm{His}$ \\
\hline $5[8]$ & Female & 28 & GD & $\begin{array}{l}\text { Gene } \\
\text { analysis }\end{array}$ & No mention & Homozygote & Exon 22 & 2552 T-A & Leu849His \\
\hline $6[9]$ & Male & 20 & $\mathrm{HT}$ & $\begin{array}{l}\text { Pathology } \\
\text { and Gene } \\
\text { analysis }\end{array}$ & JGC hyperplasia & Wild-type & - & - & - \\
\hline 7 [9] & Female & 46 & $\mathrm{GD}$ & $\begin{array}{l}\text { Gene } \\
\text { analysis }\end{array}$ & No mention & Heterozygote & Exon 1 & $185 C-\mathrm{T}$ & Thr60Met \\
\hline 8 [9] & Male & 21 & GD & $\begin{array}{l}\text { Gene } \\
\text { analysis }\end{array}$ & No mention & Homozygote & Exon 23 & $2744 G-A$ & Arg913Gln \\
\hline \multirow[t]{2}{*}{$9[10]$} & \multirow[t]{2}{*}{ Female } & \multirow[t]{2}{*}{18} & \multirow[t]{2}{*}{$G D$} & \multirow{2}{*}{$\begin{array}{l}\text { Gene } \\
\text { analysis }\end{array}$} & \multirow[t]{2}{*}{ No mention } & \multirow{2}{*}{$\begin{array}{l}\text { Compound } \\
\text { heterozygote }\end{array}$} & Exon 12 & $1015 \mathrm{~A}-\mathrm{C}$ & Thr339Pro \\
\hline & & & & & & & Exon 22 & 2573 T-A & Leu858His \\
\hline \multirow[t]{2}{*}{10 [10] } & \multirow[t]{2}{*}{ Female } & \multirow[t]{2}{*}{50} & \multirow[t]{2}{*}{ GD } & Gene & No mention & Compound & Exon 4 & 539C-A & Thr180Lys \\
\hline & & & & & & heterozygote & Exon 8 & $1045 C-T$ & Pro349Ser \\
\hline 11 [10] & Female & 56 & GD & $\begin{array}{l}\text { Gene } \\
\text { analysis }\end{array}$ & No mention & Homozygote & Exon 14 & 1706C-T & Ala569Val \\
\hline $12[11]$ & Female & 14 & GD & $\begin{array}{l}\text { Gene } \\
\text { analysis }\end{array}$ & No mention & No mention & Exon 6 & $791 \mathrm{G}-\mathrm{C}$ & Gly264Ala \\
\hline 13 [12] & Female & 20 & GD & Pathology & JGA hyperplasia & - & - & - & - \\
\hline $14[13,14]$ & Male & 21 & GD & Pathology & JGA hyperplasia & & - & - & - \\
\hline $15[14]$ & Male & 18 & GD & Pathology & JGA hyperplasia & & & - & - \\
\hline 16 [15] & Female & 39 & $\mathrm{HT}$ & $\begin{array}{l}\text { Biochemical } \\
\text { analysis }\end{array}$ & - & & & - & - \\
\hline 17 [16] & Male & 22 & GD & Pathology & JGC hyperplasia & & & & \\
\hline 18 [17] & Female & 29 & $\mathrm{HT}$ & Pathology & JGC hyperplasia & & & & \\
\hline
\end{tabular}


Table 6 Chemical indicators of the reported cases to date

\begin{tabular}{|c|c|c|c|c|c|c|c|c|c|c|c|c|}
\hline No & $\begin{array}{l}\text { Serum } \\
\text { potassium } \\
(\mathrm{mmol} / \mathrm{l})\end{array}$ & $\begin{array}{l}\text { Serum } \\
\text { magnesium } \\
(\mathrm{mmol} / \mathrm{l})\end{array}$ & $\begin{array}{l}\text { Urinary } \\
\text { calcium/ } \\
\text { creatinine }\end{array}$ & $\mathrm{pH}$ & $\mathrm{HCO}_{3}^{-}$ & FT3 & FT4 & T3 & T4 & TSH (mIU/l) & TPOAb & TRAb \\
\hline 1 & 1.4 & 0.54 & 0.23 & 7.602 & 25.2 & $\uparrow$ & $\uparrow$ & $\uparrow$ & $\uparrow$ & 0.1 & $\uparrow$ & $\uparrow$ \\
\hline 2 & 1.9 & 0.52 & 0.08 & & & $\uparrow$ & $\uparrow$ & $\uparrow$ & $\uparrow$ & 0.01 & - & $\uparrow$ \\
\hline 3 & 2.6 & 0.4 & 0.01 & & & normal & normal & & & 2.22 & $\uparrow$ & \\
\hline 4 & 3.3 & 1.8 & 0.029 & 7.458 & 29.3 & normal & normal & & & 2.02 & $\uparrow$ & \\
\hline 5 & 1.7 & 1.5 & 0.02 & 7.506 & 35.4 & $\uparrow$ & $\uparrow$ & & & 0.01 & & $\uparrow$ \\
\hline 6 & 2.67 & 0.56 & 0.05 & & 29 & $\downarrow$ & $\downarrow$ & & & 75.4 & $\uparrow$ & \\
\hline 7 & 2.3 & 0.43 & 0 & & 33 & $\uparrow$ & $\uparrow$ & & & 0.01 & $\uparrow$ & $\uparrow$ \\
\hline 8 & 2.64 & 0.36 & 0.07 & & 35 & $\uparrow$ & $\uparrow$ & & & $<0.005$ & $\uparrow$ & $\uparrow$ \\
\hline 9 & 3.2 & 0.86 & $<0.003$ & & & - & $\uparrow$ & & & 0.01 & & normal \\
\hline 10 & 3 & 0.66 & $<0.003$ & & & - & $\uparrow$ & & & $<0.005$ & & $\uparrow$ \\
\hline 11 & 2.8 & 0.49 & 0.03 & & & - & $\uparrow$ & & & 0.007 & & $\uparrow$ \\
\hline 12 & 2.2 & 0.53 & & & & $\uparrow$ & $\uparrow$ & & & 0.01 & $\uparrow$ & $\uparrow$ \\
\hline 13 & 2.46 & 0.73 & & 7.47 & & & & & & & & \\
\hline 14 & 1.87 & & & 7.45 & 27 & $\uparrow$ & normal & $\uparrow$ & normal & - & & \\
\hline 15 & 2.02 & 0.5 & & 7.55 & 28 & $\uparrow$ & $\uparrow$ & $\uparrow$ & $\uparrow$ & - & & \\
\hline 16 & 2.44 & 0.45 & & 7.488 & 27.3 & & & normal & & 4.28 & & \\
\hline 17 & 1.8 & $0.49-0.53$ & & 7.46 & 26.6 & $\uparrow$ & $\uparrow$ & & & 0.01 & normal & \\
\hline 18 & 2.65 & 0.55 & & 7.45 & 32.6 & normal & normal & & & 66.78 & $\uparrow$ & \\
\hline
\end{tabular}

Nevertheless, we still lack sufficient data to demonstrate whether AITD is more likely to occur in patients with GS. Patients with GS may undergo more extensive testing, including thyroid functional analysis, compared to healthy individuals, which may facilitate the identification of additional abnormalities. Although sufficient data are available regarding the induction of hypokalemia and hypomagnesemia by hyperthyroidism, research on the long-term effects of hypokalemia and hypomagnesemia on the thyroid is lacking. Iodine and magnesium metabolism have been found to be closely linked [21]. One study showed that long-term high dietary magnesium can lead to abnormal thyroid function. Another study suggested that hypomagnesemia may lead to rapid relapse of GD [22]. In contrast, increasing magnesium supplementation has also been shown to promote normalization of thyroid morphology and function [23].

Autoimmune thyroid diseases (AITDs) are complex genetic diseases. The genes contributing to AITD can be divided into two categories: immunomodulatory genes, including the human leukocyte antigen (HLA), cytotoxic $\mathrm{T}$ lymphocyte-related antigen 4 (CTLA-4), protein tyrosine phosphatase, nonreceptor type 22 (PTPN22), CD40, CD25, and Fc receptor-like 3 (FCRL3) genes, and thyroid-specific genes, including the thyroid-stimulating hormone receptor (TSHR) gene and the thyroglobulin (Tg) gene.
However, no studies have indicated that a correlation exists between these genes and the SLC12A3 gene.

In conclusion, GS combined with hyperthyroidism (or other AITDs) can cause hypokalemic periodic paralysis. Our patient was misdiagnosed with hypokalemic TPP for a long time, indicating that the possibility of GS should be considered in clinical cases with hyperthyroidism and persistent hypokalemia.

\section{Abbreviations}

AITD: autoimmune thyroid disease; CT: computed tomography; FT3: free triiodothyronine; GD: Graves' disease; GS: Gitelman syndrome;

HT: Hashimoto's thyroiditis; JGC: juxtaglomerular complex; PTU: propylthiouracil; TgAb: thyroglobulin antibody; TMAB: thyroid microsomal antibody; TPOAb: thyroid peroxidase antibody; TRAb: thyrotropin receptor antibody; TSH: thyroid-stimulating hormone; WBC: white blood cell

\section{Acknowledgments}

The authors thank the patient and his family for their participation.

\section{Availability of the data and materials}

All data and materials maintaining patient privacy are fully available without restriction. People can request these materials by sending an email to zhouhaiyang4000@163.com.

\section{Funding}

This work was supported by the National Natural Science Foundation of China (Grant No. 81660138).

\section{Authors' contributions}

$H Z, X L, Y Q, B M, J Z$, and $S H$ diagnosed the patient and performed the investigations and the follow-up. $\mathrm{HZ}, \mathrm{XL}, \mathrm{SL}, \mathrm{ZH}$, and $\mathrm{HY}$ analyzed the data. $\mathrm{HZ}$ and $\mathrm{XL}$ reviewed the literature, drafted the manuscript, and reviewed the 
manuscript for final publication. YM and ZL critically revised the manuscript. All authors read and approved the final manuscript.

\section{Competing interest}

The authors declare that they have no competing interests.

\section{Ethics approval and consent to participate}

This study was performed according to the Helsinki Declaration. Written informed consent to participate in the study was obtained from the patient and his mother. The patient's son was 17 years old, and written informed consent was obtained from him and his parents as legal guardians.

\section{Consent for publication}

Written informed consent was obtained from the patient and his mother for publication of the details of the case report. The patient's son was 17 years old, and written informed consent was obtained from him and his parents as legal guardians.

\section{Publisher's Note}

Springer Nature remains neutral with regard to jurisdictional claims in published maps and institutional affiliations.

\section{Received: 3 February 2018 Accepted: 27 September 2018}

\section{Published online: 08 November 2018}

\section{References}

1. Frese $\mathrm{E}$, Brown $\mathrm{M}$, Norton BJ. Clinical reliability of manual muscle testing Middle trapezius and gluteus medius muscles Phys Ther. 1987;67(7):1072-6.

2. Vargas-Poussou R, Dahan K, Kahila D, Venisse A, Riveira-Munoz E, Debaix H, et al. Spectrum of mutations in Gitelman syndrome. J Am Soc Nephrol. 2011;22(4):693-703.

3. Tago N, Kokubo Y, Inamoto N, et al. A high prevalence of Gitelman's syndrome mutations in Japanese. Hyperten Res. 2004:27:327-31.

4. Melander $\mathrm{O}$, Orhomelander M, Bengtsson $\mathrm{K}$, et al. Genetic variants of thiazide-sensitive $\mathrm{NaCl}$-cotransporter in Gitelman's syndrome and primary hypertension. Hypertension. 2000;36:389-94.

5. McLeod DS, Cooper DS. The incidence and prevalence of thyroid autoimmunity. Endocrine. 2012;42:252-65.

6. Nyström HF, Jansson S, Berg G. Incidence rate and clinical features of hyperthyroidism in a long-term iodine sufficient area of Sweden (Gothenburg) 2003-2005. Clin Endocrinol. 2013;78:768-76.

7 Dong H, Lang Y, Shao Z, Lin L, Shao L. Coexistence of Gitelman's syndrome and thyroid disease:SLCI2A3 gene analysis in two patients. Chin J Endocrinol Metab. 2010;26:395-8 (in Chinese).

8. Aoi N, Nakayama T, Tahira Y, et al. Two novel genotypes of the thiazidesensitive Na-cl cotransporter (SLC12A3) gene in patients with Gitelman's syndrome. Endocrine. 2007;31:149-53.

9. Xinyu Xu, Min sun, Xiaoyun Liu, et al. clinical feature and genetic analysis of Gitelman's syndrome accompanied by autoimmune thyroid disease. Chin J Endocrinol Metab. 2013;29:50-54. (in Chinese).

10. Mizokami T, Hishinuma A, Kogai T, et al. Graves' disease and Gitelman syndrome. Clin Endocrinol. 2016;84:149-50.

11. Zha B, Zheng P, Liu J, Huang X. Coexistence of Graves' disease in a 14-yearold young girl with Gitelman syndrome. Clin Endocrinol. 2015;83:995.

12. Xiao X, Liao E, Zhang H, Mao J, Pingan H. Gitelman syndrome with Graves's disease: a case report. Chin J Endocrinol Metab. 2006;22:91-2 (in Chinese).

13. Yayi He, Bingyin Shi, Xiaoyan Wu, et al. Gitelman syndrome complicated with hyperthyroidism and IgA nephropathy patients. Chin J Nephrol 2010; 26:70. (in Chinese).

14. Li M, Li T, He Y, Shi B. Nursing care of 2 patients with Gitelman syndrome comlicated with hyperthyroidism and lgA nephropathy. J Nurs Sci. 2015;30:33-4.

15. Shuiyu Ji, Xiang Zhao. Hashimoto's thyroiditis complicated with Gitelman syndrome: a case report. Chin I Nephrol. 2013;29:76. (in Chinese).

16. Zhenwen Zhang, Yan Zhu, Yan Wang, et al. A case of hyperthyroidism complicated with Gitelman syndrome. Chin J Postgraduates of Med 2010; 33:76-77. (in Chinese)

17. Yu Duan, Lan Luo, Chunyu Zhang, et al. Gitelman syndrome combined with primary hypothyroidism. Chin J General Practitioners 2009;8:269-270. (in Chinese).
18. Ma J, Ren $H$, Lin L, et al. Genetic features of Chinese patients with Gitelman syndrome: sixteen novel SLC12A3 mutations identified in a new cohort. Am J Nephrol. 2016;44:113-21.

19. Ren $\mathrm{H}$, Wang WM, Chen $\mathrm{XN}$, et al. Renal involvement and followup of 130 patients with primary Sjogren's syndrome. J Rheumatol. 2008;35:278-84.

20. Schwarz C, Barisani T, Bauer E, Druml W. A woman with red eyes and hypokalemia: a case of acquired Gitelman syndrome. Wien Klin Wochenschr. 2006;118:239-42.

21. Chandra AK, Goswami H, Sengupta P. Effects of magnesium on cytomorphology and enzyme activities in thyroid of rats. Indian J Exp Biol. 2014:52:787-92.

22. Klatka M, Grywalska E, Partyka M, Charytanowicz M, Rolinski J. Impact of methimazole treatment on magnesium concentration and lymphocytes activation in adolescents with Graves' disease. Biol Trace Elem Res. 2013:153:155-70.

23. Moncayo R, Moncayo H. The WOMED model of benign thyroid disease: acquired magnesium deficiency due to physical and psychological stressors relates to dysfunction of oxidative phosphorylation. BBA Clin. 2015;3:44-64.
Ready to submit your research? Choose BMC and benefit from:

- fast, convenient online submission

- thorough peer review by experienced researchers in your field

- rapid publication on acceptance

- support for research data, including large and complex data types

- gold Open Access which fosters wider collaboration and increased citations

- maximum visibility for your research: over $100 \mathrm{M}$ website views per year

At BMC, research is always in progress.

Learn more biomedcentral.com/submissions 